\title{
Bio-prospecting of Medicinal Bio-resources from the Kenyan Biodiversity: Reflections on Governance as the Missing Link - A Review Article
}

\author{
Micheni Ndii Kiraithe ${ }^{1,4 *} \quad$ Muthee John K. ${ }^{2} \quad$ Mathiu Peter M. ${ }^{3} \quad$ Muthama Nzioka J. ${ }^{4}$ \\ 1.School of Biological Sciences, College of Biological \& Physical Sciences, University of Nairobi, P.O Box \\ 30197-00100, Nairobi, Kenya. \\ 2.Department of Clinical Studies, College of Agriculture \& Veterinary Sciences, University of Nairobi, P.O Box \\ 29053-00625, Nairobi, Kenya. \\ 3.Department of Veterinary Anatomy and Physiology, College of Agriculture \& Veterinary Sciences, University \\ of Nairobi, P.O Box 29053-00625, Nairobi, Kenya. \\ 4.Wangari Maathai Institute of Peace and Environmental Studies, University of Nairobi, 'P.O Box 29053-00625, \\ Nairobi, Kenya.
}

The research was financed by National Research Fund Agency, Kenya (Ref. No. A82/51244/2016).

\section{Abstract}

Medicinal biodiversity has since times immemorial served as one of the richest sources of bio-prospecting leading to the discovery of novel drugs for mankind globally. However, in Kenya, despite the Country being known to be a mega biodiversity hotspot, bio-prospecting has not been very successful mainly due to lack of effective institutional and legal frameworks. This article reviews the policy and legislation instruments governing medicinal biodiversity in Kenya in order to identify their weaknesses and strengths and come up with recommendations for effective economic exploitation of the Country's' mega diverse resource. The methodology employed was a qualitative content analysis of relevant biodiversity legislations in Kenya. Results reveal that there has been governance gaps as far as bio-prospecting activities in Kenya are concerned which has rendered the Country's mega biodiversity vulnerable to bio-piracy at the expense of the poor local communities who are the traditional knowledge owners. There is need to review the current pieces of legislation on medicinal biodiversity and work towards developing a strong National bio-prospecting policy together with an implementation plan. These are important to inform the overall national development agenda, in tandem with Vision 2030. Some of the policies were found out dated and rather obsolete and not serving the current interests and ambitions of the Country. There is therefore a need to revisit the policy and legislative instruments because they will continue frustrating bioprospecting activities. Moreover, we recommend the creation of a National Institute to coordinate and harmonize the legislations and National policies on medicinal biodiversity to seal loopholes, avoid conflicts and contradictions being experienced in the current legislative and policy frameworks.

Keywords: Bio-prospecting; Bio-piracy; Governance; Kenya; Medicinal biodiversity

DOI: $10.7176 / \mathrm{JHMN} / 60-05$

Publication date:March $31^{\text {st }} 2019$

\section{INTRODUCTION}

Biodiversity is the backbone of Kenya's national economy. Its use value cuts across board into the sectors of agriculture, wildlife, tourism, health, forestry, water, fisheries, and into all areas of ecology and ecosystem services. Globally, it is a well - known fact that the biodiversity base has been eroding gradually but quite fast in the recent times. Anthropogenic activities are wiping out biodiversity and interfering with the smooth functioning of healthy ecosystems whose benefits if lost would be costly to reinstate. The goods and services they provide will become increasingly rare and highly sought after (MA 2005).

Likewise, since the advent of modern biotechnology, the establishment of the World Trade Organization (WTO) and the advancement in genetic engineering, there is a rush to mine biodiversity and convert it into a corporate commodity. This mining is commonly referred to as bio-prospecting. Bio-prospecting is the exploration of biodiversity for commercially valuable biological compounds useful as medicines, food, chemicals and, enzymes (Eisner 1989, Reid et al., 1993). It applies to plants, animals and all living organisms, including bacteria and fungi.

Bio-prospecting can also include the collection of traditional knowledge relating to the use of these resources from local communities. The wealth of traditional knowledge available in different cultures if subjected to prospecting can yield valuable leads in developing novel drugs/pharmaceuticals of great industrial value. Medicinal biodiversity has served as one of the richest sources of bio-prospecting thus leading to novel drug discoveries that have profoundly contributed to human health (Craig and Newman, 1999). For instance, many of the World's most valuable and successful medicines have been derived from nature.

Bio-prospecting for genetic resources has not only been internationally recognized as important for 
development but also as a potential threat to sustainable use of biodiversity especially for the developing countries including Kenya. Despite the country being considered to be one of the world's mega-biodiverse countries, the level of bio-prospecting falls below its potential producing only limited economic benefits. Instead, the country has been a fertile ground for un-coordinated bio-prospecting and bio-piracy activities. As such, the country may therefore benefit or lose from the use or demand for her biodiversity resources. The situation will largely be dictated by her biodiversity use policies as well as the status of the existing scientific, technical and technological knowledge base. The country therefore requires a strong policy and legal framework to help in exploitation of her rich biodiversity for economic benefits while safeguarding it against bio-piracy.

Globally, the key International law instruments that govern bio-prospecting, access and benefit sharing (ABS) are the Convention on Biodiversity (CBD) and the Bonn Guidelines on ABS (CBD, 1992). In Kenya, the government (GOK) has already put in place most of the legal and institutional instruments for bio-prospecting. For example, Kenya is a party to all the relevant multilateral environmental agreements (MEAs) such as the Convention on Biological Diversity (CBD 1992) and its related protocols - the Cartagena Protocol on Biosafety, and the Nagoya Protocol on Access and Benefits Sharing. Similarly, she is party to the United Nations Framework on Climate Change (UNFCC) and the associated Kyoto Protocol [10]. Other relevant MEAs are the Convention on Migratory Species (CMS 1979), the Convention against the International Trade in Endangered Species (CITES 1973), the United Nations Convention to Combat Drought and desertification (UNCCD 1992), the Convention on Wetlands of International Importance (RAMSAR 1971), and United Nations Convention on the Law of the Sea (UNCLOS 1982). These MEAs provide fora for discussion on how best to manage the affected fauna and flora for sustainable development.

The GOK has also enacted several legislations related in one way or the other to the above MEAS with the goal of facilitating their implementation and subsequently enhancing the accruing of benefits to all. Some of these include the Environmental Management and Co-ordination Act (EMCA 2000); the National Biodiversity Strategy and Action Plan (NBSAP), the Legal Notice No. 160 (2006) on the Conservation of Biological Diversity and Resources, Access to Genetic Resources and Benefit Sharing; the Bio-prospecting Strategy within and outside protected areas in Kenya (2001); Prior Informed Consent (PIC) Procedures; Mutually Agreed Terms (MAT) and Material Transfer Agreements (MTA) [CBD 1992]. However, In Kenya, the provisions of the Environmental Management and Coordination Act (EMCA, 1999), and the Environmental Management and Coordination (Conservation of Biological diversity and Resources, access to Genetic Resources and Benefit Sharing\} Regulations 2006 takes the centre stage as far as matters to do with bio-prospecting are concerned.

Last but not least, the Kenya Constitution 2010 provides for compliance with international law. Article 2(5) and (6) states inter alia..."the general rules of international law shall form part of the laws of Kenya" and "any treaty or Convention ratified by Kenya shall form part of the laws of Kenya under this constitution". Finally, Article 10 on National values and principles of governance include sustainable development and binds the state to enact and implement legislation to fulfill its international obligations in respect of human rights and fundamental freedoms of which sustainable use of biodiversity is one of them (The Constitution of Kenya 2010).

In this paper, we single out and offer a critique on some pre-colonial, colonial and post-colonial medicinal biodiversity governance instruments and interrogate them to what extent they have supported or impeded the search that could form the basis of new pharmaceutical discoveries. Second, we will single out known bio-piracy case studies resulting from governance gaps highlighted. Third, in the context of successful future bio-prospecting in Kenya, we argue that medicinal biodiversity governance needs to be reviewed and strengthened to accelerate the pace of new discoveries.

\section{Methodology}

The method adopted in this research involved the analysis of the available Parliamentary laws, bills and policy documents that relate to medicinal biodiversity in Kenya from various sources including internet and the available printed policy documents from the relevant Institutions. This information was then compared with those in other Countries with established systems in order to establish the existing inadequacies. The various efforts to have documented medicinal biodiversity incorporated into mainstream healthcare and the legal framework is also reviewed.

\section{Results}

\subsection{Pre-colonial Cultural governance system - Cultural erosion}

Pre-Colonial era in Kenya dates back to the period before 1895 when Kenya was declared a protectorate of the British Empire. During this era, medicinal biodiversity like other resources was protected under cultural controls and regulations guided by community elders in various Community settings. In most communities, traditional rulers and beliefs steered medicinal biodiversity governance with rules being enforced by a council of elders and fetish priests who provided technical and spiritual advice (Dore 2001). Traditional sustainable use of medicinal plants was regulated by management practices such as taboos, seasonal and social regulations on harvesting of 
medicinal plants which served to limit medicinal plant harvesting thus making traditional medicine (TM) the only mode of healthcare. Peoples Cultures/Traditions have been very instrumental in new innovations/discoveries. In conventional medicine, majority of drug discoveries have been derived from leads pursued from traditional knowledge of communities living in harmony with nature.

The Colonial period in Kenya was from 1895 to 1962 before Kenya became a self governing state. During that time there was the advent of western cultures through the Colonial administrators, Religious missionaries and local devotees who trivialized and demonized the Kenyan cultures thus eroding them. They were classified as "satanic" "primitive" or "sorcery". They urged the Kenyan people to modernize and move beyond their "tribal" inheritance and embrace the newer 'more progressive' cultures. There was introduction of cash economy and government controls which led to decline of traditional cultural practices and controls. For example, before the arrival of the Europeans in Kenya, the communities who lived around Mount Kenya believed that God dwelt on the mountain, and that their basic supplies raging from drinking water, rains, crops for their food, flowed from it. Upon the arrival of Christian Missionaries in the area toward the end of nineteenth century, they convinced the locals that God lived in heaven and not on Mount Kenya, and that the mountain and its forests previously considered sacred grounds could be encroached upon and the reverence accorded to them abandoned. These changed their perceptions and were persuaded to consider their relationship with the mountain and, indeed, nature itself as primitive, worthless and an obstacle to development (Wangari Maathai, 2010).

When the white settlers and then the local communities themselves cut down the trees to plant coffee and tea and other agricultural products, encroaching farther up the mountain, there was little resistance. This led to clearance of certain medicinal tree species, for example, Prunus africana which takes many years to grow and mature. Such interferences might have led to the extinction of multiple species which would have otherwise been bio-prospected for medicines to treat some of the incurable disease conditions today such as Hypertension, HIV/AIDS and Cancer.

\subsection{Inheritance of outdated laws from Colonial Masters - Witchcraft Act of 1925}

There are some policies in our Kenyan Laws that would act as impediments in the Country's efforts to harness its medicinal biodiversity. A case in point is the "Witchcraft Act of 1925" that was enacted during the colonial period by the Colonial masters. Currently, the Witcheraft Act is under CAP 67, Laws of Kenya. This is an act of the Parliament of Kenya which provides that "any person who of his pretended knowledge of so-called witcheraft, intends to injure, cause fear, annoyance or injury in mind, person or property to, any person shall be guilty of an offense (Witchcraft Act, 1925). Since the colonial time (1925) when this Act was enacted to date, diviners and healers who used herbal and other animal derived medicines were misconceived and condemned wholesale as "Witchdoctors", "Wizards", or "Witches". Fifty five years post colonially, this Act is still in force, and the perception is the same. This has seen many innocent diviners and healers arrested, arraigned in court, fined or imprisoned and their paraphernalia confiscated and destroyed. Such an Act by all standards denies traditional bioprospectors freedom to open up on their discoveries which may presumably be termed as witchcraft thereby giving them a direct ticket to a jail.

\subsection{Inadequate implementation of World Health Organization (WHO) Strategies/ Policies 3.3.1 The Alma - Atta Declaration - 1978}

This was an International Conference on primary Health Care organized by the WHO in Alma-Ata in USSR. (Alma- Ata Declaration). The Alma - Ata declaration among other things officially underscored the role of traditional medicine in health systems and the need to engage Traditional medicine practitioners and birth attendants in primary health care and training them accordingly as important resources for achieving "Health for All by the year 2000". It also emphasized on the need to produce scientific research findings in support of traditional medicine. It goes without saying that traditional medicine as a product cannot be appreciated in isolation without appreciating medicinal biodiversity which provides the raw materials. The medicinal diversity in this case is obviously plants, animals and microorganisms.

\subsubsection{Chiang Mai Declaration - 1988}

This declaration was made by a team of experts on the conservation of medicinal plants who had convened for an International Consultative Meeting in Chiang Mai, Thailand (Chiang Mai Declaration). The Consultative Meeting was organized by WHO, IUCN and WWF bringing together experts at the meeting who included administrators and policy makers in health and conservation, and covered the disciplines of ethno-medicine, botany, education, pharmacology, nature conservation and economics. The participants prepared and issued "The Chiang Mai Declaration - Saving Plants that Saves Lives"- which affirms the importance of medicinal plants and calls on the United Nations, its agencies and Member States, as well as other International organizations to take action for the conservation of medicinal plants so as to ensure that adequate quantities are available for future generations.

\subsubsection{African Decade on African Traditional medicine (2001 - 2010)}

The Decade for African Traditional Medicine was declared in July 2001 by the Member States of the WHO African 
Region during the Summit of the Organization of African Union (OAU) Heads of States and Governments held in Lusaka, Zambia. It was to cover the period of 2001 to 2010. The Organization of African Union (OAU) decision was a historic collective expression of political will in recognition of African traditional medicine signifying tremendous support of its rational development, improvement and integration into public health care systems in the region. The Strategy was dubbed "Promoting the role of traditional medicine in health care systems: A Strategy for the African Region". This was after African Countries failed to realize the objective of "Health for All by the year 2000" as was envisaged in the previous Strategy "Alma Atta Declaration of 1978".

The African decade in African Traditional medicine Strategy provided for the Institutionalization of traditional medicine in health care systems of the Member States of the WHO African Region. There were model guidelines developed by the WHO regional Director for Africa and his Secretariat which some among others were of governance significance such as: i, Guidelines for the formulation, implementation, monitoring and evaluation of a National Traditional Medicine Policy; ii, Model legal framework for the practice of traditional medicine; the Traditional Health Practitioners Bill; iii, Regional framework for the registration of traditional medicines in the WHO African region; A regulatory framework for the protection of Intellectual Property Rights (IPR) and indigenous knowledge of traditional medicines in the WHO African Region.

All the stakeholders stood to gain a great deal upon implementation of these guidelines. In particular, all the practitioners in traditional medicine would have gained professionally as well as economically. Traditional medicine encompasses the exploitation of medicinal biodiversity using traditional knowledge. Promotion of traditional medicine including its incorporation in the Country's health care system will go a long way in promoting bio-prospecting activities since the traditional medicine practitioners will reveal some of their knowledge which they have jealously guarded as secrets over a long period of time.

\subsection{Conflicting policies - Presidential decree on Aloe, 1986.}

Trade in aloe is illegal in Kenya following the 1986 Presidential decree (CITES 2003). This decree prohibited harvesting of the species from the wild for commercial purposes. The decree however encouraged establishment of aloe plantations for commercial exploitation of the species. The ban was however never gazetted to give it legal teeth. This then poses the question on how cultivated aloe would be distinguished from wild aloe for the purposes of commercial exploitation.

\subsection{Inadequate implementation of Convention of Biological Diversity (CBD)}

The CBD is an important global agreement on matters of biodiversity. It was one of the major outcomes of the Earth Summit held in Rio de Jainero (CBD, 1992)]. The CBD has three main goals namely: The conservation of the environment; the sustainable use of the components of biodiversity and; the sharing of benefits arising from the commercial and other utilization of genetic resources in fair and equitable way. Kenya being a member of Mega-diverse Countries that are rich in biological diversity signed the CBD in 1992 and ratified it in July 1994. The CBD has a number of Articles as far as accessing medicinal biodiversity for drug discovery is concerned that set the tone for future interactions between Bio-prospectors and Research Organizations with countries having the desired biodiversity.

Of interest to bio-prospecting under the CBD is the adoption of the Bonn Guidelines on "Access to Genetic Resources and fair and Equitable Sharing of the Benefits arising out of their utilization (ABS)" in 2002. These Guidelines were intended to help all parties follow best practices in setting up bio-prospecting agreements. In Kenya, the Guidelines were enacted by the National Environmental Authority (NEMA) as Conservation of Biological Diversity and Resources, Access to Genetic Resources and Benefit Sharing Regulations in 2006, to strengthen the ABS regime which took effect in January 2008. It took Kenya nearly fifteen (15) years from the date when the CBD came into force and the time when Regulations to govern ABS regime were enacted, a period during which both bio-prospectors and bio-pirates might have taken advantage of the situation.

In addition, Kenya's EMCA ABS Regulations 2006 has various shortcomings which need to be addressed at the earliest opportunity possible to attract both traditional and modern bio-prospectors. These are as follows:

Whereas Article 13 of the Bonn Guidelines provides that each party should designate one national focal point for access and benefit sharing and make such information available through the clearing house mechanism, the EMCA Regulations 2006 do not make such provisions for the establishment of one national focal point for bioprospecting. The failure to make such provision makes the process of administering bio-prospecting and ABS permits tedious where applicants hop from one office to another in pursuit of various requirements.

The EMCA ABS Regulations 2006 do not specify the minimum contents of both benefit sharing and material transfer agreements. There ought to be specific minimum provisions and the agreements also ought to be in a prescribed format. In addition, the ABS agreements must be required to be specific about the type and quantity of resources to be collected, the area from where they are to be collected, traditional uses of the resource as well as the extent to which the community and interested parties will share in the benefits.

In the material transfer agreement, some necessary safeguards have been left out. The agreement should be 
required to state the type and quantity of resources to be provided, the area of collection, the purpose for collecting, the uses and the conditions under which the recipient may transfer such material to a third party.

While the Regulations sets out benefits, it is not clear at all who is to achieve the monetary and non-monetary benefits. There is no indication either as to how the same will be channeled to the relevant stakeholders and the Community. This therefore creates gaps for diversion of benefits and unnecessary bureaucracy around benefit sharing.

Under Regulation 2, the community is to be involved in the negotiation of a Material Transfer Agreement and further under Regulation 9 (2), the Community must be one termed as interested persons from whom prior informed consent is required before access permit is issued and thus identified as stakeholder under the permitting provisions. Thus, the Community is a vital link between bio-prospecting and ABS. However, the EMCA $A B S$ Regulations do not define the term Community as used therein. Failure to define with clarity what the term Community comprises as used under the Regulations makes it difficult for bio-prospectors to identify with certainty whom to deal with.

It is further observed that the bio-prospectors while doing access applications has to visit various offices and Institutions such as NACOSTI, Local Authorities Administrators and others prior to making a formal application making the process unnecessarily long. The Regulations ought to have simplified and shortened the process by making it a one stop shop application process to attract bio-prospectors as earlier recommended by Article 13 of Bonn guidelines.

\subsection{Contradicting legal frameworks on medicinal biodiversity - Convention of Biological Diversity (CBD) verses World Trade Organization (WTO) - Trade Related Aspects of Intellectual Property Agreement (WTO- TRIPS)}

Kenya is a signatory to most of the Multilateral Environmental Agreements (MEAs) and has committed herself through Article 2 section (5) of the constitution, that the general rules of International law shall form part of the law of Kenya (Constitution of Kenya 2010). In addition, she has domesticated these MEAs at National level. However, some of these laws especially those on medicinal biodiversity lack harmonization. Some are too general, conflicting and at times contradictory. The case of the CBD and TRIPS demonstrates well how contradictory these MEAs can be (WTO-TRIPS).

The overall goal of the CBD is to sustain a biological diversity through International collaboration between developed and developing nations while acknowledging the rights of local communities. Article 1 in the CBD calls for a "fair and equitable sharing of the benefits arising out of the utilization of genetic resources including by appropriate access to genetic resources and by appropriate transfer of relevant technologies, taking into account all rights over those resources and technologies, and by appropriate funding". Article $8 \mathrm{j}$ further develops the need to protect indigenous knowledge from exploitation as it calls for the contracting States to: respect, preserve and maintain knowledge, innovations and practices of indigenous and local communities embodying traditional lifestyles relevant for the conservation and sustainable use of biological diversity and promote their wider application with the approval and involvement of the holders of such knowledge, innovations and practices and encourage the equitable sharing of the benefits arising from the utilization of such knowledge, innovations and practices.

On the other hand, WTO-TRIPS does not acknowledge Indigenous Communities rights to their own traditional knowledge while it enforces Western Companies' possibilities to patent scientific findings based on such knowledge. According to the Convention criteria defined by Western Intellectual Property Law, traditional knowledge and indigenous use of medicinal plants are considered to be neither new nor innovative and thus not qualified for protection as IP. However, when these substances are taken to the laboratory by the Western Manufacturing Companies, turned into pharmaceutical or cosmetic products, they become new and innovative.

\subsection{Adoption of Neo-colonial exploitative Agreements (Laws) - World Trade Organization (WTO)-Trade Related Aspects of Intellectual Property Agreement (TRIPS)}

There are some International Agreements that are suggestive of neo-colonialist mode of exploitation of the Developing Countries by the Developed Countries. These are enforced through trade International Institutions and agreements. WTO- TRIPS is an example of such agreements, which requires all WTO members to implement certain Intellectual Property Rights (IPR) standards in their national legislation. The IPR agenda set down in $W T O-$ TRIPS thus protects resources that are likely to be appropriated by Western Companies while it excludes resources that local and indigenous groups in developing Countries could lay claim to.

Of significant to bio-prospecting, WTO-TRIPS does not acknowledge Indigenous Communities rights to their own traditional knowledge while it enforces Western Companies' possibilities to patent scientific findings based on such knowledge. According to the Convention criteria defined by Western Intellectual Property Law, traditional knowledge and indigenous use of medicinal plants are considered to be neither new nor innovative and thus not qualified for protection as IP. However, when these substances are taken to the laboratory by the Western 
Manufacturing Companies, turned into pharmaceutical or cosmetic products, they become new and innovative. The application of patent definitions thus becomes a mechanism that denies traditional owners the rights to that knowledge and passes it to other actors who can redefine that knowledge according to the definition prescribed by IPR (Oguamanam 2006).

\subsection{Inadequate protection of Intellectual Property Rights (IPRs)}

Medicines derived from biodiversity using traditional or indigenous knowledge is referred to as Traditional medicine. Traditional medicine encompasses knowledge and practices used for diagnosis, prevention and cure. A greater part of indigenous knowledge refers to the properties of natural materials especially medicinal plants, animal parts and minerals (Sandiiga et al., 1995). In addition, traditional medicine encompasses a great variety of methods of diagnosis and treatment, including physical, mental and special therapies. Traditional medicine includes knowledge concerning medicines and their use, appropriate dosage, particular forms of administration, as well as the procedures and rituals applied by healers as part of their traditional healing methods.

While some products used in the context of traditional medicine, as well as the processes for their preparation, may find protection of IPRs, some methods of diagnosis and treatment generally would not, due to their peculiarities, unless specifically protected under national laws. It is the knowledge, products and processes that have become of concern with regard to intellectual property rights.

Protection of intellectual property rights is one of the important means of promoting bio-prospecting activities from traditional knowledge. This is because many activities and products based on traditional medicine are important sources of income (NCAPD, 2007). Traditional medicine in Kenya remain non-codified (Not formalized in written form) and include what have generally been termed "folk" or "rural", "tribal" and" indigenous" which has been handed over orally from generation to generation in communities. They are generally based on traditional beliefs, norms and practices based on centuries old experiences of trials and errors, successes and failures at the household and community levels. Thus a significant part of traditional medicine in Kenya remains trade secrets with the herbal traditional practitioners.

In Kenya, the only instrument available for protecting traditional knowledge is the trade secret. The Industrial Property Act Cap 509 of the Laws of Kenya, which could protect the intellectual integrity of traditional practitioners, disqualifies traditional knowledge. Medicinal biodiversity is therefore collected and used without any regulation, opening it to indiscriminate exploitation and bio-piracy. Huge profits are made but never shared with the custodians of this bio-resource.

\subsection{Ineffective Traditional knowledge preservation policy on medicinal biodiversity - National policy on traditional knowledge, genetic resources and cultural expressions (2009)}

Both modern and traditional bio-prospecting requires a very strong traditional knowledge preservation policy on medicinal biodiversity since strong cues from traditional knowledge has historically led to new drug discoveries. In Kenya, the issue of Traditional knowledge in medicinal biodiversity has of late been addressed thanks to the National policy on traditional knowledge, genetic resources and cultural expressions (2009). Kenya has a large number of tribes and each has its own peculiar customs and beliefs. The use of herbal medicine is equally different among the communities. Despite this, most of the medications have not been documented and scientifically evaluated to determine their efficacy and dosage vis-à-vis the alleged indications by the practitioners. These medications have been in use for centuries and it is quite possible that they could possess some degree of potency and can potentially be used for therapy of some of the current conditions. Hence there is need to identify these plants and document them for future reference and research (IEA, 2011a).

There is a lot of potential on Traditional knowledge in Kenyan herbal medicine judging from the published laboratory results from the screening of plant extracts that have been analyzed in various Institutions. However, in as much as we are doing well on this, there is need to document the information from traditional practitioners in order to provide a comprehensive database for future research with potential for the development of new drugs. There are some genuine concerns arising from the realization that the old generations that holds this knowledge are fast aging and the young generation do not seem to take much interest in advancing this knowledge. The rapid deforestation exacerbates the situation. The knowledge for the potential cures for diseases such as cancer may therefore be extinct before the clues are released to the scientists for research.

However the most encouraging bit is that there are several publications with regards to the products obtained from the extracts of some of these plants, with quite a number showing pharmacological activities and potential for the development of new pharmaceutical products (Irungu et al., 2012, Langat et al., 2012, Matheka et al., 2012). The development of a database containing information on both the ethno-botanical and the properties of the extracts from plants is important for future research and development. On the contrary, the Chinese traditional medicines are recorded and thanks to this we now have a leading cure of malaria from the wormwood (Artemesia annua Spp) that was used in China more than a thousand years ago (Hsu, 2006). 


\subsection{Enactment of biased laws: Anti-doping Act, 2016 of the Laws of Kenya}

This is an Act of Parliament of Kenya that makes provision for the implementation of the United Nations Education, Scientific and Cultural Organization (UNESCO) Convention against doping in sports. The ultimate aim of the Act is to protect the health of athletes through regulating sporting activities and ensuring that they are devoid of prohibited substances (Anti-doping act 2016). Section 42(4) of the Act provides that a Medical Practitioner, Pharmacist, Veterinary Surgeon, Dentist, Nurse, Physiotherapist, Traditional herbalist or any other Health professional who; a, prescribes or dispenses prohibited substances or methods to an athlete with the intent of doping; b, unlawful use of prohibited substances or method to an athlete; c, acquires stocks or is found in unlawfully possession of prohibited substances or; $d$, aids or abates or in any way encourages the unlawful use of prohibited substances commits an offense and shall be liable upon conviction to a fine of not less than 3 million Kenya Shillings or to an imprisonment of not less than 3 years or to both such fine and imprisonment and shall have his or her professional license revoked for a period of not less than 1 year (Anti-doping act 2016).

Parts $\mathbf{c}$ and $\mathbf{d}$ of this Act are of special interest to us in as far as administration of herbal medicine by herbal practitioners is concerned. Monotherapy in herbal medicine rarely works. More often, medicinal herbs are administered in combination with others for optimum results. From the foregoing, it is interesting to note that this Act is almost criminalizing herbal practice in entirety since the herbal practitioners at one time or the other may be possessing the "prohibited substances" not necessarily stored for use by the athletes but as ingredients to his or her day to day drugs synergistic formulations. Just like in conventional medicine, the use of a good prescribed drug for the wrong reason is referred to as drug abuse. The misuse of drugs by the drug addicts over time has not criminalized the Medical Practitioners who are the doctors, pharmacists and even nurses. The law will be selective or rather biased to criminalize herbalists in this context. Moreover, the imposition of a huge penal fine and (or) imprisonment obviously deters potential breakers (Herbalists) for my argument shake, from being aggressive to share their knowledge on these substances and their plant sources, a move that works against bio-prospecting.

3.11 Absence of a National policy framework for promoting and regulating use of medicinal biodiversity: Stalled Draft policy on Traditional medicine and medicinal plants (2010)

Bio-prospecting from traditional medicine can be from different activities such as cultivation of medicinal plants for sale or production and distribution of herbal remedies. There are various plant derived drugs in conventional medicine worldwide, three quarters of which were discovered through scientific investigation of traditional medicine (Marles and Famsworth, 1996). Well known examples of plant-derived medicines include Paclitaxel, the most widely used breast cancer drug, antimalarials quinine \& artemisinin and digitalis for cardiac failure. Kenya has several plant species that have medicinal value but are under threat. These include Aloe secundiflora, Prunus africana and Zanthoxylum chalybeum. Unfortunately, despite the majority of Kenyan population relying greatly on traditional medicine de facto, for their primary health care, there is no national policy framework in place to provide a sound base for both promoting and regulating its use. There is virtually no investment in cultivation of medicinal plants. Instead, many Kenyans, depend on natural forests to extract the majority of plant material consumed by the traditional medicine Industry.

In 2007, the Kenyan Government embarked on a process of consultations with the relevant stakeholders to address the needs of traditional medicine sector, culminating in the development of a Draft policy on Traditional medicine and medicinal plants. This policy was aimed at achieving conservation of medicinal plants, equitable sharing of benefits and enhancing production and domestication, while ensuring the safety and efficacy of the products. The draft policy was also to give guidance to practitioners, consumers and regulators (NCAPD, 2007). Despite the draft policy being worked into a bill that was tabled before Parliament in the year 2010, the bill flopped and up to date, it has never seen the light of the day. In my view, there were vested interests with the status quo since even ten years down the line, such an important bill has not been re-visited.

\subsection{Absence of bio-prospecting policy}

The absence of a bio-prospecting policy has attracted another form of commercial exploitation targeting the medicinal plants that have been identified to have direct medicinal uses.

Examples:

The case of Prunus africana bark: The bark was discovered to be effective in the management of benign prostatic hyperplasia 35 years ago. The extract is formulated and sold as capsules (pygeum africanum) by pharmaceutical companies mainly in Europe. This has led to increased harvesting to the extent that it was declared endangered by the convention of International trade in Endangered species (CITES) in 1995 (Stewart, 2003). Similarly, the sandalwood tree (Osyris lanceolata) has been illegally harvested for both medicinal and cosmetic purposes in Kenya and exported to Europe or Asia (WildlifeDirect, 2009). Several other plants have been exploited for medicinal uses including Warburgia ugandensis, Pausinystalia johimbe (used as aphrodisiac), Griffonia simflicifolia (mood disorders), and Harpagophytum procumbens (pain management) [Wamalwa et al., 2006]. Uncontrolled harvesting of Mondia whytei locally referred to as "Mukombero" has been reported in Western 
Kenya. The local Communities believe that its roots have aphrodisiac capabalities (RNW, 2011). Several Aloe species in Kenya have also been listed as threatened due to overexploitation for commercial activities (CITES 2003).

\subsection{Absence of policy on Microbial bio-resources}

In Kenya, bioresources (biodiversity) is directly governed using the Flora and Fauna Acts that are in place. The Flora related Acts include the Kenya Forest Act 2005 and the Agriculture Act 2003, while the Fauna related Acts include the Kenya Wildlife Act 2013. Despite microorganisms being an important component of biodiversity and of late being at the centre of bio-prospecting research globally, there is no clear and specific governance structure in Kenya. Microbial bio-resource activities are regulated by National Environmental management Authority (NEMA) under Environmental management Coordination Act (EMCA), 1999 and the Environment Management and Coordination (Conservation of biological diversity and resources, access to genetic resources and benefits sharing regulations, of 2006.

The manner by which microorganisms are regulated through EMCA 1999 and the CBD Regulations 2006 is ambiguous and therefore can be a hindrance as far as microbial bio-prospecting is concerned. For example, in 2007 using NEMA regulations, Kenya Wildlife Service by virtue of having jurisdiction over the management of Kenya's 61 national parks and reserves entered into a five year partnership agreement with Novozymes, a biotech company based in Denmark, for collection, identification, and characterization of micro-organisms from Kenya's national parks. This then begs the question whether bacteria is an animal, whether KWS in their human resource have competent Microbiologists to oversee the partnership, and also whether there are microorganisms outside the National parks/ reserves in Kenya. In the partnership between KWS and Novozymes, KWS facilitated acquisition of research and clearance permits based on the conditions for access and benefits sharing as stipulated in parts III and IV of the NEMA regulations.

In their Agreement, KWS was to do all collections from Kenyan national parks and reserves while the Novozymes was to set up a Microbial discovery laboratory and train researchers staffed by KWS. These researchers were to isolate and characterize microorganisms and later supply results to Novozymes, who would decide whether to pursue a lead or not. Novozymes is known to have a very active patenting policy, with a portfolio of more than 4,200 active patents. This prompts us to ask the question: for whose benefit was the laboratory and even results. From the discussion above, we can infer that the Denmark Company Novozymes, was capitalizing on the lack of microbial governance policy and probably Kenya did not benefit as much as it would have benefited from the agreement.

\subsection{Absence of Zootherapy policy}

Like plants, animals and their products also possess medicinal properties. The healing of human diseases by using therapeutics derived from animals is known as zootherapy. Up to this far, there has been no attempts to develop policies on zootherapy in Kenya, like there were attempts to develop a national policy on Traditional medicine and medicinal plants in 2010. Bio-prospecting from animal biodiversity in Kenya is anchored in the role of KWS in its overall Institutional legal mandate to conserve and manage wildlife in the Country and enforce the related laws and regulations namely: The Wildlife Conservation and Management Act Cap 376 and The Wildlife Conservation and Management (Amendment) Act no. 16 of 1989 and The Wildlife Conservation and Management Act, 2013. It holds in trust, Kenya's genetic resources, both flora and fauna, excluding domesticated species for the Kenyan people. Sessional paper No. 3 of 1975 deals with revocation of dealers in Wildlife products which is upheld by legal notice 1978 and International Protocols and treaties like the CITES. It is worthy to note that dealers in Wildlife medicine (products) were not spared. This particular policy has silently criminalized the practice and trade in animal medicine (zootherapy) and consequently criminalizing bio-prospecting activities using animal bioresources.

\section{Bio-piracy}

Bio-piracy may be termed as the act of engaging in bio-prospecting contrary to national and International laws. It is essentially the appropriation of intellectual property rights gleaned from indigenous knowledge or biological resources for commercial gain without recognition of the indigenous communities who originally developed the indigenous knowledge or the country or community from whom the biological resources are obtained, benefiting from the commercialization. Bio-piracy is also referred to when biodiversity or knowledge about diversity is collected and patented without permission from the owners of these resources. Bio-piracy is about stealing of bioresources and associated knowledge from traditional or indigenous communities, individuals or from the Country. In Kenya, there has been cases of bio-piracy which have come to the public limelight in the recent past. We will highlight the following three examples to emphasize the magnitude of the underlying challenges: 


\subsection{The case of extremophile micro-organisms from Lake Nakuru in 1992}

In 1992, a British researcher collected extremophile micro-oganisms from Lake Nakuru. The microbes collected produce industrially important enzymes that are used for fading jeans wear. A California based bio-tech Company known as Genecor subsequently patented, cloned and sold the microbes. The patent was registered as US Patent 6,291,229 issued on $18^{\text {th }}$ September 2001. These important enzymes have generated millions of Dollars for the industry. Kenya did not approve the collections and no benefits have accrued to Kenyans ( www.edmonds.institute.org.).

\subsection{The case of a bacteria strain from Lake Ruiru}

In 1995, a German Pharmaceutical giant Bayer which sells and markets Acarbose (a drug that is used as an alpha glucosidase inhibitor in the management of type II diabetes) filed a patent on a new way to manufacture Acarbose using a bacteria strain SE 50 that had unique genes. This bacteria strain was from Lake Ruiru in Kenya. The sales of Acarbose are estimated to be more than US\$ 379 million per annum. There was neither prior informed consent from Kenya nor have any benefits accrued to Kenya in relation to the commercialization of the microbe (www.edmonds.institute.org)

\subsection{The case of Novozymes and Kenya's microbial diversity in protected areas}

In 2007, the Kenya Wildlife service (KWS) entered into a 5 year agreement research partnership with a Danish company called Novozymes in regard to characterization of Kenya's microbial diversity. The agreement granted Novozymes rights to exploit for commercial use enzymes that are found within KWS controlled areas which have enormous industrial applications potential especially in biofuels, detergent manufacture, analysis of drugs or blood samples, in food additives and medicines. A number of benefits were to accrue to KWS including milestone payment and royalties arising from commercialization, technology transfer and training. It is noteworthy that while this agreement was entered into in May 2007, Novozymes had been carrying on research and bio-prospecting activities in the same protected areas for several years even before 2007. In fact, the agreement was a late attempt to legitimize an illegitimate venture and despite the coming into force of the EMCA ABS Regulations, neither KWS nor Novozymes has obtained a bio-prospecting permit from NEMA, and therefore the activities carried out under the agreement are illegal (www.edmonds.institute.org).

\section{Conclusion}

In conclusion, we opine that; i, Cultural preservation of traditional knowledge of the different communities of Kenya should be of principal concern to the government. This is because communities traditional knowledge gives clues which are pursued in majority of drug discoveries; ii, Thou biodiversity is the biological capital of any nation and that the success of a nation depends upon the capability of her people to convert their biodiversity and other natural resources into wealth in an ecologically sound and economically rewarding and sustainable manner using Science and Technology, the government of Kenya (GOK) has not demonstrated seriousness on this agenda. As it is, there is no policy framework in place to govern exploitation and commercialization of medicinal plants, animals or even microorganisms. Thou there were unsuccessful efforts to legislate Traditional medicine and medicinal plants bill in 2010, the authors are not aware of any attempts to legislate zootherapy and microbial therapy; iii, The country is poor by choice. Despite Kenya being touted to be a biodiversity hot spot, she has chosen not to exploit her biodiversity potential to the fullest to improve the livelihoods of its citizenry. The government of Kenya despite reviewing her Constitution in 2010 retained some laws inherited from colonialism that continue to serve as hindrances to bio-prospecting activities. The "Withchcraft Act (1925) serves as an example of such laws. Some of these laws are not serving the current situation, interests and ambitions especially regarding Kenyan's Vision 2030; iv, Kenya should not rush to signing some of the Multilateral Agreements since some are neo-colonial in nature. While we appreciate the fact that Kenya being part of the global village cannot live in isolation, there is every reason to be cautious and open our eyes widely to read between the lines while signing and ratifying some of the International Conventions, Agreements and Treaties. After all, the United States of America despite being a Super Power and expected to lead by example, is not a signatory to some of these Agreements including the CBD and UNFCCC. It is worthy to note that some of the International Agreements could be playing some International politics. Also, the question of vested interests by developed countries on developing countries cannot be ruled out; $\mathrm{v}$, There is non-coherence in implementation of CBD in National Laws. Despite the CBD being the key legal framework governing bio-prospecting in Kenya, there are several gaps, loopholes, overlaps and disconnect in the implementation of CBD related conventions and Treaties in Kenya. In particular, there is no proper coordination in implementation of the Environmental Management and co-ordination of biological Diversity and Resources, Access to genetic Resources and Benefit Sharing) Legal Notice No. 160 of 2006. There are various Ministries that deal with biological resource related legislations. There are also several Lead agencies under the different Ministries managing biological resources that sometimes conflict one another. There is need to conduct research on the existing legislations and Institutional frameworks in the Country and develop a National Bio-prospecting 
policy which can lead to creation of a National Institute to coordinate the legislations and national policies; vi, Even though bio-prospecting is expensive and may take some time to realize its benefits, the government of Kenya should appreciate that the utilization of the enormous biological resources by its citizenry will impact on the socioeconomic development thus contributing to the achievement of the vision 2030.

\section{Acknowledgements}

The authors are greatly indebted to the University of Nairobi, and in particular, Wangari Maathai Institute, through the director Prof. Henry Mutembei, for the tremendous support, guidance and encouragement while working on this article. The Government of Kenya through the National Research Fund Agency is highly appreciated for its goodwill and willingness to fund the study responsible for producing this article.

\section{References}

Anti-doping Act (2016). Section 42 (4). Laws of Kenya. Kenya Gazette Supplement No. 74 (National Assembly Bills No. 15).

CITES (2003). Review of significant Trade East African Aloes: http://www.cites.org /eng/com/pc/14/E-PC14-0902-02-A4.pdf. (Accessed on 20/09/2018).

Convention against the International Trade in Endangered Species (1973).

Convention of Biological Diversity (1992). https://www.cbd.int/doc/legal/cbd-en.pdf (Accessed on 11/06/2018).

Convention on the Conservation of Migratory species of Wild Animals (1979).

Convention on Wetlands of International Importance (1971).

Craig, GM \& Newman DJ. (1999). Discovery and development of antineoplastic agents from natural sources. Cancer Invest 17: 153-63.

Dore D. (2001). Transforming Traditional Institutions for Sustainable Natural Resource Management: History, Narratives and Evidence from Zimbabwe's Communal Areas. African Studies Quarterly (2001) Volume 5 Issue 3.

Eisner, T. (1989). Prospecting for nature's chemical riches ISS. Sci. Technol. 6: 31-34.

Environmental Management Coordination Act (2000).

Hsu, E. (2006). Reflections on the "discovery" of the antimalarial qinghao Br. J. Clin. Pharmacol. Ther. 1: 106109.

IEA, (2011a). Biodiversity, Traditional knowledge and Intellectual property in Kenya: www.ieakenya.or.ke (Accessed on 02/10/2018).

Irungu NB, Mbabu MJ. Kiboi DM, Moindi E. Kinyua J and Romano M. (2012). In vivo antimalarial and acute toxicity properties of hexane and chloroform extracts from Clausena anisata (Willd.). Benth. Afr.J. Pharmacol. Ther. 1: 24-29.

Kenya Constitution (2010).

Langat BK, Siele DK. Wainaina C, Mwandawiro C, Ondicho J, Tonui WK, Anjili, Cireri LN, CK, M. (2012). Larvicidal effects of Mundulea serica (Leguminosaea) plant extract against Aedes aegypt (L.) (Diptera: Culicidae) Afri. J. Pharmacol. Ther. 1: 106-109.

Laws of Kenya Act Title: Witchcraft (2016).

Matheka DM, Alkizim FO Kiama TN and Bukachi F. (2012), Glucose-lowering effects of Momordica charantia (Karela) extract in diabetic rats. Afri. J. pharmacol. Ther. 1: 62-66.

Millenium Assessment (2005).

National Coordinating Agency for Population and Development (NCAPD), "Draft Policy on Traditional medicine and Medicinal plants," Nairobi, (2007).

National Coordinating Agency for Population and Development (NCAPD). "Draft Policy on Traditional medicine and medicinal plants" Nairobi, (2007).

NCAPD Policy Brief No. 1, Seeking solutions for Traditional herbal medicines: Kenya Develops a National Policy.

Nicolaou KC, Chen JS, Dalby SM. (2009). From nature to the Laboratory and into the Clinic. Bioorg Med Chem; 17 (6): 2290- 303

Oguamanam, C. (2006). International Law and Indigenous Knowledge: Intellectual Property, Plant Biodiversity and Traditional Medicine. Toronto: University of Toronto Press.

R. Marles \& N. Farnsworth (1996). "Antidiabetic plants and their action constituents: An update", Prof. J.Bot. med; 3:85-135.

Reid, W.V; Laird, S.A; Meyer, C.A; gamez, R; Sittenfeld, A; Janzen, D.H; Gollin, M.A. and Juma, C. (1993) (Eds). Biodiversity Prospecting Using Genetic Resources for Sustainable Development, WRI, Washington DC.

RNW (2011). Radio Netherlands Worldwide Africa: Kenyans chew potency drug to extinction: http://www.rnw.nl/africa/article/kenyans-chew-potency-drug-extinction. (Accessed on 26/9/2018).

Sandiga, Chacha, C.N; \& Kanunah, M.P. (1995). Traditional medicine in Africa. The existence and use of 
Traditional medicine in Kenya (e-book). Nairobi: East African Educational Publishers Ltd. Available online: http://books.google.com/books (accessed on 11/10/2018).

Stewart, KM. (2003). The African cherry (Prunus Africana): Can lessons be learned from an overexploited medicinal tree? J. Ethnopharmacol. 89: 3-13.

United Nations Convention on the Law of the Sea (1982).

United Nations Convention to combat Desertification (1992).

United Nations Framework on Climate Change (1992).

Wamalwa N. Oballa P \& Gicheru J. (2006). Genetic variation of Wsarburgia ugandensis in Kenya and Implications for its cultivation. Kenya Forestry Research Institute (KEFRI). Nairobi, Kenya. PP. 90-93.

Wangari Maathai (2010). The Challenges of Africa.

Wildlife Direct (2009). WildlifeDirect Inc. saving Kenya's Forests. Perfumery sends sandalwood numbers down (http://kenyaforests.wildlifedirect.org). Accessed on 15/05/2018.

World Health Organization Alma - Ata (1978). Primary Health care: Report of the International Conference on Primary Health Care. Alma-Ata, USSR, 6-12 (Health for All Series, No.1).

www.edmonds.institute.org (Report titled Out of Africa: Mysteries of Access and Benefits Sharing, P 31 of the Report. (Accessed on 29/11/2018). 